\title{
Goats as alternative hosts of cattle ticks
}

\author{
N. NYANGIWE ${ }^{1}$ and I.G. HORAK ${ }^{2}$
}

\begin{abstract}
NYANGIWE, N. \& HORAK, I.G. 2007. Goats as alternative hosts of cattle ticks. Onderstepoort Journal of Veterinary Research, 74:1-7

The objective of this study was to compare the presence on goats and cattle of adult ticks that usually infest cattle. To this end ticks collected from sets of five goats were compared with those collected from sets of five cattle at 72 communal dip-tanks in the eastern region of the Eastern Cape Province. Amblyomma hebraeum was present on goats at 25 and on cattle at 39 dip-tanks, and a total of 61 goats and 138 cattle were infested. Adult Rhipicephalus (Boophilus) microplus was present on goats at 48 and on cattle at 69 dip-tanks, and a total of 113 goats and 242 cattle were infested. The lengths of 84 of 148 female $R$. (Boophilus) microplus collected from the goats exceeded $5 \mathrm{~mm}$ or more, indicating that they could successfully engorge on these animals. The differences between the proportions of dip-tanks at which A. hebraeum or $R$. (Boophilus) microplus was present on goats and cattle and also between the proportions of goats and cattle that were infested were significant (Chisquare test, $P<0.01$ ). Adult Rhipicephalus appendiculatus was present on goats at 70 and on cattle at 67 dip-tanks, and a total of 296 goats and 271 cattle were infested. The proportion of dip-tanks at which cattle were infested did not differ significantly from the proportion of tanks at which goats were infested (Fischer's exact probability test, $P=0.44$ ), but the proportion of infested cattle was significantly lower than the proportion of infested goats (Chi-square test, $P<0.05$ ). Adult Rhipicephalus evertsi evertsi was present on goats and cattle at all 72 sampling localities, and a total of 334 goats and 316 cattle were infested. The proportion of infested cattle was significantly lower than the proportion of infested goats (Chi-square test, $P<0.05$ ). These results underscore the necessity of including goats in any tick control programme designed for cattle at the same locality.
\end{abstract}

Keywords: Adult ixodid ticks, alternative hosts, Amblyomma hebraeum, cattle, Eastern Cape Province, goats, Rhipicephalus (Boophilus) microplus, Rhipicephalus appendiculatus, Rhipicephalus evertsi evertsi

\section{IINTRODUCTION}

Four tick species are of major economic importance as vectors of diseases that affect domestic cattle in

1 Döhne Agricultural Development Institute, Private Bag X15, Stutterheim, 4930 South Africa; and Department of Veterinary Tropical Diseases, Faculty of Veterinary Science, University of Pretoria, Onderstepoort, 0110 South Africa.

E-mail: nkululeko@dohne.agric.za

2 Department of Veterinary Tropical Diseases, Faculty of Veterinary Science, University of Pretoria, Onderstepoort, 0110 South Africa; and Division of Parasitology, ARC-Onderstepoort Veterinary Institute, Onderstepoort, 0110 South Africa

Accepted for publication 15 September 2006-Editor southern Africa. These are Amblyomma hebraeum, the vector of Ehrlichia (Cowdria) ruminantium, the cause of heartwater in cattle, sheep, goats and certain wild ruminant species (Allsopp, Bezuidenhout \& Prozesky2004), Rhipicephalus(Boophilus) decoloratus, the vector of Babesia bigemina, the cause of babesiosis or African redwater in cattle (De Vos, De Waal \& Jackson 2004), Rhipicephalus (Boophilus) microplus, an introduced tick, which is responsible for the transmission of both B. bigemina and Babesia bovis, the latter the cause of Asiatic redwater in cattle (De Vos et al. 2004), and Rhipicephalus appendiculatus, the vector of Theileria parva, the cause of 
theileriosis in cattle (Lawrence, Perry \& Williamson 2004a, b). A fifth tick, Rhipicephalus evertsi evertsi, which is a vector of Babesia caballi and Theileria equi, the cause of piroplasmosis in horses (De Waal \& Van Heerden 2004), has a preference for horses in all its stages of development, but is also a common parasite of cattle, goats and sheep (Norval 1981; Walker, Keirans \& Horak 2000).

Several surveys have been conducted on the ticks that infest cattle and goats in South Africa. Some of these have focused only on cattle (Baker \& Ducasse 1967; Londt, Horak \& De Villiers 1978; Schröder 1980) and others only on goats (Rechav \& De Jager 1991; Boomker, Horak \& Ramsay 1994; Maclvor \& Horak 2003), while a third group have included both cattle and goats at the same locality and same time (Baker \& Ducasse 1968; Rechav 1982; Horak, Knight \& Williams 1991; Horak 1999; Bryson, Tice, Horak, Stewart \& Du Plessis 2002a, b), or in tandem (Fourie \& Horak 1990, 1991; Fourie, Kok \& Heyne 1996).

There are no tick species that infest either of these hosts to the exclusion of the other, but whereas goats are often the hosts of large numbers of immature ticks and fewer adults (Baker \& Ducasse 1968; Bryson et al. 2002a; Maclvor \& Horak 2003), cattle may harbour large numbers of both adult and immature ticks (Baker \& Ducasse 1967; Horak 1982, 1999; Rechav 1982; Bryson et al. 2002b). There may, however, also be considerable proportional differences in the species composition of adult ticks on goats and cattle on the same farm (Fourie et al. 1996). After examining goats at five localities at which cattle were also present, Baker \& Ducasse (1968) came to the conclusion that goats played an important role in maintaining tick infestations on stock farms in KwaZulu-Natal Province, and that they should be included in tick control programmes applied to cattle.

The opportunity to compare the species composition of ticks on goats and cattle examined in numerically equal small groups at the same time at several localities arose during a survey on the geographic distribution of ticks in the eastern region of the Eastern Cape Province, South Africa. The objective of the present communication is to highlight the role of goats as hosts of adult ticks of species that usually infest and transmit diseases to cattle.

\section{MATERIALS AND METHODS}

Within the five municipal districts that constitute the eastern region of the Eastern Cape Province, there are 1057 communal dip-tanks at each of which there are $\mathbf{2 0 0}$ or more cattle registered, and 75 of these dip-tanks were selected for survey purposes. At each dip-tank five healthy adult goats, preferably with visible tick infestations, and five healthy, but preferably visibly tick-infested, year-old cattle were examined. Adult ticks were collected from the ears, bodies, bellies, feet, tails and peri-anal regions of these animals on the single occasion that each dip-tank was visited. The ticks were stored in $70 \%$ ethyl alcohol in labelled vials for later identification and quantification under a stereoscopic microscope.

The length of the idiosoma of engorging female $R$. (Boophilus) microplus collected from the goats was measured and the number of maturing (also referred to as standard) females determined. The idiosomal length of a standard $R$. (Boophilus) microplus female is $4.5-8.0 \mathrm{~mm}$ in length and is an indication that she will fully engorge and detach within the next $24 \mathrm{~h}$ (Wharton \& Utech 1970). The same procedure was not followed with the ticks collected from cattle because living engorging and engorged female $R$. (Boophilus) microplus were required for acaricide resistance tests. We have chosen to use the name $R$. (Boophilus) microplus as proposed by Murrell \& Barker (2003) after Murrell, Campbell \& Barker (2000) and Beati \& Keirans (2001) had shown that the genus Rhipicephalus is paraphyletic with respect to the genus Boophilus. Many people, however, prefer to retain Boophilus as a generic name.

The collections of ticks from each goat or bovine were not intended to be exhaustive and consequently the numbers of ticks recovered from these animals cannot be compared. However, the presence or absence of particular tick species on the two host species as well as at the various dip-tanks can be compared. A Chi-square test was used to compare the proportion of dip-tanks at which goats were positive for each of the four tick species with the proportion of dip tanks at which cattle were positive for the same species.

It was possible to sample five goats and five cattle at 72 of the 75 selected dip-tanks and consequently the presence or absence of ticks on 360 goats could be compared with that on the same number of cattle. A Chi-square test was used to compare the proportion of positive goats to the proportion of positive cattle for each of the tick species, and Wilcoxon's signed rank test for matched pairs was used to compare the difference between the number of infested goats and the number of infested cattle at each diptank. 
For comparative purposes the numbers of ticks collected from goats and cattle during previous surveys conducted at various localities in South Africa have been summarized and presented in tabular format.

\section{RESULTS}

Amblyomma hebraeum was present on goats at 25 and on cattle at 39 dip-tanks, and a total of 61 goats and 138 cattle were infested (Fig. 1). The proportion of dip-tanks at which goats were infested differed from the proportion of tanks at which infested cattle were present (Chi-square test, $P<0.05)$. The proportion of cattle infested with $A$. hebraeum was higher than the proportion of goats (Chi-square test, $P<$ 0.01 ), and the median of the difference between the number of infested cattle and infested goats was greater than zero $(P<0.01)$.

Rhipicephalus (Boophilus) microplus was present on goats at 48 and on cattle at 69 dip-tanks, and a total of 113 goats and 242 cattle were infested (Fig. 1). The proportion of dip-tanks at which goats were infested differed from the proportion of tanks at which infested cattle were present (Chi-square test, $P<$
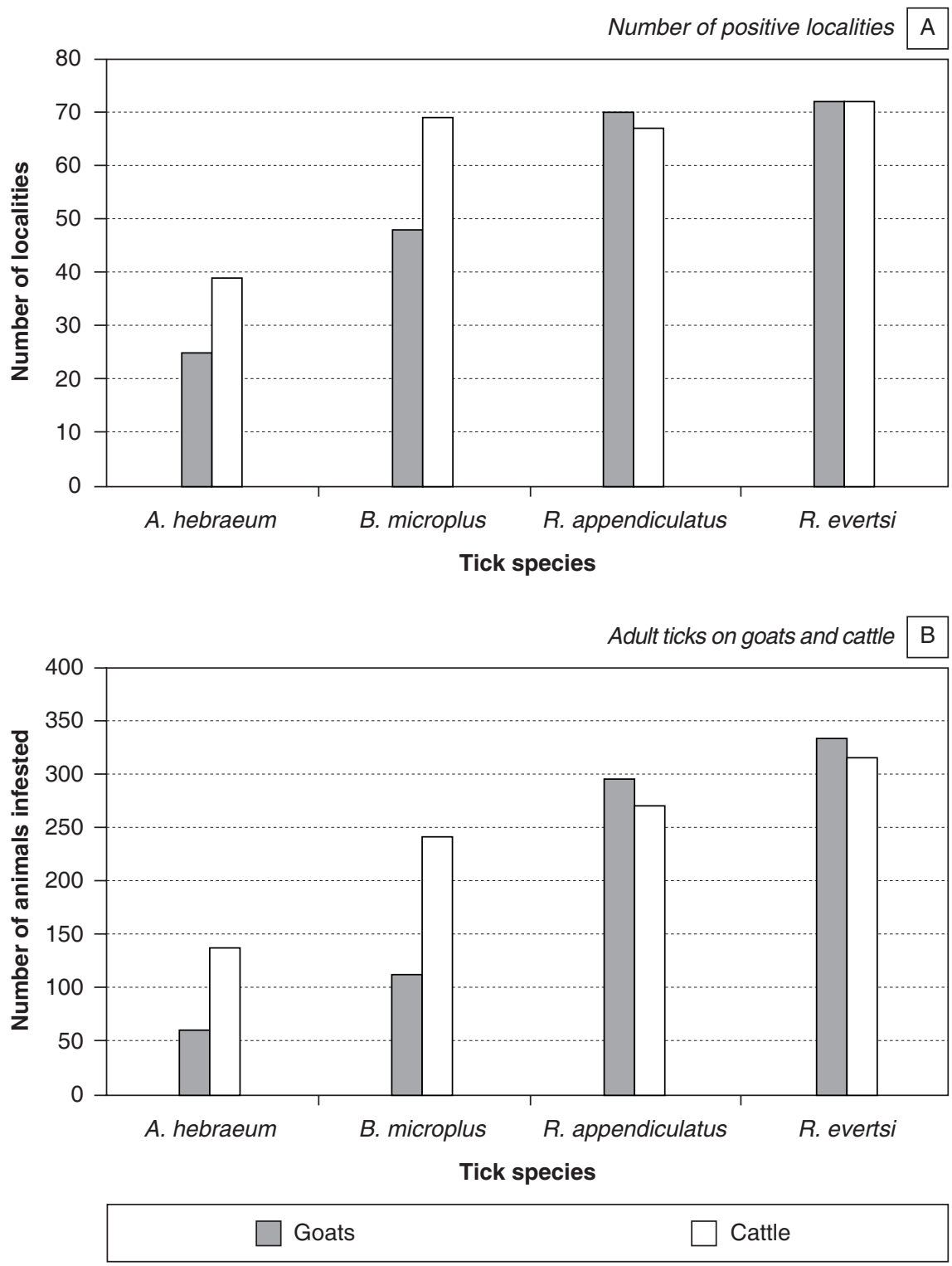

FIG. 1 The numbers of (A) dip-tanks at which Amblyomma hebraeum, Rhipicephalus (Boophilus) microplus, Rhipicephalus appendiculatus and Rhipicephalus evertsi evertsi were present on goats and cattle, and the total numbers of (B) goats and cattle on which these ticks were present at 72 dip-tanks in the eastern region of the Eastern Cape Province, South Africa 
Goats as hosts of cattle ticks

TABLE 1 Numbers of ticks collected in previous surveys from goats and cattle examined at the same localities in various provinces of South Africa

\begin{tabular}{|c|c|c|}
\hline \multirow[t]{2}{*}{ Province and Tick species } & \multicolumn{2}{|c|}{ Total No. of adult ticks (total No. of collections) } \\
\hline & Goats & Cattle \\
\hline KwaZulu-Natal Province ${ }^{1}$ & Untreated & Untreated \\
\hline Amblyomma hebraeum & $26(10)$ & $312(20)$ \\
\hline Rhipicephalus (Boophilus) microplus & 266 (all stages) (9) & 32692 (all stages) (18) \\
\hline Rhipicephalus appendiculatus & $179(39)$ & $782(70)$ \\
\hline Rhipicephalus evertsi evertsi & $184(48)$ & $662(88)$ \\
\hline Eastern Cape Province ${ }^{2}$ & Untreated, but ran with a treated herd & Untreated in previous 5 weeks \\
\hline Amblyomma hebraeum & $16(48)$ & $1092(46)$ \\
\hline Rhipicephalus appendiculatus & $60(48)$ & $1244(46)$ \\
\hline Rhipicephalus evertsi evertsi & $3(48)$ & $74(46)$ \\
\hline North West Province ${ }^{3}$ & Untreated & Untreated in previous 7 days \\
\hline Amblyomma hebraeum & $90(123)$ & $3461(141)$ \\
\hline Rhipicephalus appendiculatus & $38(123)$ & $1387(141)$ \\
\hline Rhipicephalus evertsi evertsi & $226(123)$ & $836(141)$ \\
\hline Mpumalanga Province ${ }^{3}$ & Untreated & Untreated in previous 7 days \\
\hline Amblyomma hebraeum & $6(30)$ & $72(36)$ \\
\hline Rhipicephalus appendiculatus & $32(30)$ & $38(36)$ \\
\hline Rhipicephalus evertsi evertsi & $404(30)$ & $37(36)$ \\
\hline Free State Province ${ }^{4}$ & Untreated & Untreated \\
\hline Hyalomma marginatum rufipes & $41(750)$ & $2598(397)$ \\
\hline Hyalomma truncatum & $72(750)$ & $270(397)$ \\
\hline Ixodes rubicundus & $2052(750)$ & 4565 (397) \\
\hline Rhipicephalus evertsi evertsi & $3(750)$ & $197(397)$ \\
\hline Rhipicephalus warburtoni & $3782(750)$ & $562(397)$ \\
\hline
\end{tabular}

1 Baker \& Ducasse (1968)

2 Horak et al. (1991) and Horak (1999)

3 Bryson et al. (2002a, b)

4 Fourie \& Horak $(1990,1991)$ and Fourie et al. (1996)

0.01). The proportion of infested cattle was higher than the proportion of infested goats (Chi-square test, $P<0.01$ ), and the median of the difference between the number of infested cattle and infested goats was greater than zero $(P<0.01)$. One hundred and forty-eight female $R$. (Boophilus) microplus that had been collected from the goats were measured and 84 of these were $5 \mathrm{~mm}$ or more in length, implying that they would probably engorge and detach within the next $24 \mathrm{~h}$.

Rhipicephalus appendiculatus was present on goats at 70 and on cattle at 67 dip-tanks, and a total of 296 goats and 271 cattle were infested. The proportion of dip-tanks at which goats were infested did not differ from the proportion of tanks at which cattle were infested (Fischer's exact probability test, $P=0.44$ ). However, the proportion of cattle infested was lower than the proportion of goats (Chi-square test, $P<$ 0.05 ), and the median of the difference between the number of infested cattle and infested goats was equal to zero $(P=0.1)$.

Rhipicephalus evertsi evertsi was present on goats and cattle at all 72 dip-tanks, and a total of 334 goats and 316 cattle were infested (Fig. 1). The proportion of infested cattle was lower than the proportion of infested goats (Chi-square test, $P<0.05$ ), and the median of the difference between the number of infested cattle and of infested goats was less than zero $(P<0.05)$.

With the exception of Free State Province, in which certain species of ticks collected from goats and cattle differed considerably from those on goats and cattle examined in other provinces, the same three or four major species were collected at most localities (Table 1). Apart from R. evertsi evertsi on goats in Mpumalanga Province, and Rhipicephalus warburtoni on goats in Free State Province, cattle ex- 
amined at the same localities as goats invariably harboured more adult ticks than did goats that were infested with the same species.

\section{DISCUSSION}

Horak, Maclvor, Petney \& De Vos (1987) concluded that the larger the host species the greater the likelihood that it would harbour large numbers of adult $A$. hebraeum, and this was confirmed by the present findings. In ten collections made over a period of a year from a goat in Thornveld in KwaZulu-Natal, Baker \& Ducasse (1967) recovered a total of 26 adult $A$. hebraeum. The total number collected from two calves sampled at the same times as the goat at the same locality, where no stock had been dipped in an acaricide for the previous 6 years, was 312 adult ticks (Table 1). Horak, Knight \& Williams (1991) collected a total of 16 adult ticks from 48 adult Angora goats that were slaughtered in pairs at monthly intervals on a farm in Valley Bushveld in the Eastern Cape Province. Forty-six young cattle that were also slaughtered in pairs at monthly intervals at the same locality as the goats, were infested with a total of 1092 adult $A$. hebraeum. Goats can, however, harbour larger numbers of adult ticks of this species and Rechav \& De Jager (1991) recovered approximately 1160 adult ticks in 220 collections made from goats over a period of 22 months in Limpopo Province. Maclvor \& Horak (2003) collected totals of 387 and 214 adult ticks from 24 Angora and 24 of Boer goats respectively, that were each slaughtered in pairs at monthly intervals on a farm in Valley Bushveld in the Eastern Cape Province.

Rhipicephalus (Boophilus) microplus uses cattle as hosts and is usually only found on other animals provided infested cattle are present at the same locality. Baker \& Ducasse (1967) recovered a total of 266 ticks in all stages of development in nine consecutive collections from a goat, while the total yield of nine collections from two calves at the same locality was 32692 ticks (Table 1). Mason \& Norval (1980) recorded 81 collections of $R$. (Boophilus) microplus from cattle and a single collection each from a goat and a horse during the National Tick Survey conducted in Zimbabwe. Horak, Sheppey, Knight \& Beuthin (1986) recovered $R$. (Boophilus) microplus from a grey rhebok, Pelea capreolus, grazing with cattle outside the Bontebok National Park near Swellendam in the Western Cape Province, South Africa, but not one of 59 of these antelopes examined inside the park, where no cattle are permitted, was infested (Horak et al. 1986; Horak \& Boomker 1998).
The recovery of $R$. (Boophilus) microplus from goats at so many localities in the present study can be ascribed to the high prevalence of infestation on cattle at the same dip-tanks (Fig. 1), and to the fact that questing $R$. (Boophilus) microplus larvae were collected from the vegetation at 62 of the 72 survey sites (Nyangiwe \& Horak, unpublished data 2006). A more significant finding, however, is the large proportion of female ticks $5 \mathrm{~mm}$ or more in length collected from the goats. This is a good indication that the ticks were successfully completing their life cycles on the goats and could perhaps even do so in the absence of infested cattle to replenish their infestations. If this is so, a further adaptation to several wildlife species, particularly bushbuck, Tragelaphus scriptus and greater kudus, Tragelaphus strepsiceros, that share much of their habitat with goats in the Eastern Cape Province, and are excellent hosts of the closely related $R$. (Boophilus) decoloratus (Horak, Potgieter, Walker, De Vos \& Boomker 1983; Horak, Boomker, Spickett \& De Vos 1992), may be imminent.

Minimum temperature requirements for $R$. (Boophilus) microplus in Africa are approximately $4^{\circ} \mathrm{C}$ lower than those required by the same species in South America, and in contrast to ticks in the latter region, African R. (Boophilus) microplus can withstand periods of low rainfall during the winter months (EstradaPeña, Bouattour, Camicas, Guglielmone, Horak, Jongejan, Latif, Pegram \& Walker 2006). Moreover, crossbreeding experiments between South African and Australian R. (Boophilus) microplus resulted in hybrid sterility (Spickett \& Malan 1978), indicating additional mutations in South African $R$. (Boophilus) microplus. An adaptation by this tick to a new host species may thus not be an unrealistic expectation.

Domestic cattle and large herbivores such as greater kudus and male nyalas, Tragelaphus angasii, are hosts favoured by $R$. appendiculatus (Baker \& Ducasse 1967; Horak 1982; Horak et al. 1992; Horak, Boomker \& Flamand 1995). Horak et al. (1991) collected a total of only 60 adult ticks from 48 adult Angora goats, while 46 young cattle on the same farm harboured a total of 1244 adult $R$. appendiculatus (Table 1). Twenty-five greater kudus examined on the farm and on an adjacent nature reserve harboured a total of 604 adult ticks (Horak et al. 1992). Although the actual numbers of ticks collected from goats and from cattle in the present study cannot be compared, 25 more goats at three more localities than cattle were infested with adult ticks. 
Rhipicephalus evertsi evertsi has the most widespread distribution of all ticks belonging to the genus Rhipicephalus in Africa, and also has one of the largest host ranges (Walker et al. 2000). The preferred hosts of all its parasitic life stages are domestic and wild equids, but large numbers may infest cattle, goats and sheep (Norval 1981; Walker et al. 2000). Baker \& Ducasse (1968) collected more adult ticks from untreated cattle than from goats at five localities in KwaZulu-Natal Province, but the converse was true for goats in Mpumalanga Province (Bryson et al. 2002a; Table 1). In the present study ticks were collected from both goats and cattle at all 72 survey localities, but a total of 334 goats compared to 316 cattle were infested with adult ticks (Fig. 1).

\section{CONCLUSIONS}

The results of this study indicate that goats are good hosts of most of the economically important ticks that infest cattle, and that $R$. (Boophilus) microplus, which has previously been considered a cattle tick, may be in the process of adapting to goats. In the light of these findings it is imperative to include goats in any tick control programme applied to sympatric cattle.

\section{ACKNOWLEDGEMENTS}

We thank the Department of Agriculture of the Eastern Cape Province for the support and the facilities that they have provided towards this project. We are most grateful to the goat and cattle owners who allowed us to collect ticks from their animals. Prof. J.O. Nöthling of the Department of Production Animal Studies, Faculty of Veterinary Science, University of Pretoria, very kindly performed the statistical analyses for us. The project was financed by funds provided by Bayer HealthCare South Africa and by the Technology and Human Resources for Industry Programme (THRIP) of the Department of Trade and Industry in conjunction with the National Research Foundation. The publication of this study has been facilitated through the Integrated Consortium on Ticks and Tick-borne Diseases (ICTTD-3), financed by the International Cooperation Program of the European Union through Coordination Action Project No. 510561.

\section{REFERENCES}

ALLSOPP, B.A., BEZUIDENHOUT, J.D. \& PROZESKY, L. 2004. Heartwater, in Infectious diseases of livestock, $2^{\text {nd }}$ ed., edited by J.A.W. Coetzer \& R.C. Tustin. Cape Town: Oxford University Press Southern Africa.

BAKER, M.K. \& DUCASSE, F.B.W. 1967. Tick infestation of livestock in Natal. I. The predilection sites and seasonal variations of cattle ticks. Journal of the South African Veterinary Medical Association, 38:447-453.

BAKER, M.K. \& DUCASSE, F.B.W. 1968. Tick infestation of livestock in Natal. The role played by goats as reservoirs of the economically important cattle ticks. Journal of the South African Veterinary Medical Association, 39:55-59.

BEATI, L. \& KEIRANS, J.E. 2001. Analysis of the systematic relationships among ticks of the genera Rhipicephalus and Boophilus (Acari: Ixodidae) based on mitochondrial 12S ribosomal DNA gene sequences and morphological characters. Journal of Parasitology, 87:32-48.

BOOMKER, J., HORAK, I.G. \& RAMSAY, K.A. 1994. Helminth and arthropod parasites of indigenous goats in the northern Transvaal. Onderstepoort Journal of Veterinary Research, 61:13-20.

BRYSON, N.R., TICE, G.A., HORAK, I.G., STEWART, C.G. \& DU PLESSIS, B.J.A. 2002a. Ixodid ticks on indigenous goats owned by small-scale farmers in four communal grazing areas in South Africa. Journal of the South African Veterinary Association, 73:26-30.

BRYSON, N.R., TICE, G.A., HORAK, I.G., STEWART, C.G. \& DU PLESSIS, B.J.A. 2002b. Ixodid ticks on cattle belonging to small-scale farmers at four communal grazing areas in South Africa. Journal of the South African Veterinary Association, 73:98-103.

DE VOS, A.J., DE WAAL, D.T. \& JACKSON, L.A. 2004. Bovine babesiosis, in Infectious diseases of livestock, $2^{\text {nd }}$ ed., edited by J.A.W. Coetzer \& R.C. Tustin. Cape Town: Oxford University Press Southern Africa.

DE WAAL, D.T. \& VAN HEERDEN, J. 2004. Equine piroplasmosisis, in Infectious diseases of livestock, $2^{\text {nd }}$ ed., edited by J.A.W. Coetzer \& R.C. Tustin. Cape Town: Oxford University Press Southern Africa.

ESTRADA-PEÑA, A., BOUATTOUR, A., CAMICAS, J.-L., GUGLIELMONE, A., HORAK, I., JONGEJAN, F., LATIF, A., PEGRAM, R. \& WALKER, A.R. 2006. The known distribution and ecological preferences of the tick subgenus Boophilus (Acari: Ixodidae) in Africa and Latin America. Experimental and Applied Acarology, 38:219-235.

FOURIE, L.J. \& HORAK, I.G. 1990. Parasites of cattle in the south western Orange Free State. Journal of the South African Veterinary Association, 61:27-28.

FOURIE, L.J. \& HORAK, I.G. 1991. The seasonal activity of adult ixodid ticks on Angora goats in the south western Orange Free State. Journal of the South African Veterinary Association, 62:104-106.

FOURIE, L.J., KOK, D.J. \& HEYNE, HELOISE 1996. Adult ixodid ticks on two cattle breeds in the south-western Free State, and their seasonal dynamics. Onderstepoort Journal of Veterinary Research, 63:19-23.

HORAK, I.G. 1982. Parasites of domestic and wild animals in South Africa. XV. The seasonal prevalence of ectoparasites on impala and cattle in the Northern Transvaal. Onderstepoort Journal of Veterinary Research, 49:85-93.

HORAK, I.G., POTGIETER, F.T., WALKER, JANE B., DE VOS, V. \& BOOMKER, J. 1983. The ixodid tick burdens of various large ruminant species in South African nature reserves. Onderstepoort Journal of Veterinary Research, 50:221-228. 
HORAK, I.G., SHEPPEY, K., KNIGHT, M.M. \& BEUTHIN, C.L. 1986. Parasites of domestic and wild animals in South Africa. XXI. Arthropod parasites of vaal ribbok, bontebok and scrub hares in the western Cape Province. Onderstepoort Journal of Veterinary Research, 53:187-197.

HORAK, I.G., MACIVOR, K.M. DE F., PETNEY, T.N. \& DE VOS, V. 1987. Some avian and mammalian hosts of Amblyomma hebraeum and Amblyomma marmoreum (Acari: Ixodidae). Onderstepoort Journal of Veterinary Research, 54:397-403.

HORAK, I.G., KNIGHT, M.M. \& WILLIAMS, E.J. 1991. Parasites of domestic and wild animals in South Africa. XXVIII. Helminth and arthropod parasites of Angora goats and kids in Valley Bushveld. Onderstepoort Journal of Veterinary Research, 58:253-260.

HORAK, I.G., BOOMKER, J., SPICKETT, A.M. \& DE VOS, V. 1992. Parasites of domestic and wild animals in South Africa. XXX. Ectoparasites of kudus in the eastern Transvaal Lowveld and the eastern Cape Province. Onderstepoort Journal of Veterinary Research, 59:259-273.

HORAK, I.G., BOOMKER, J. \& FLAMAND, J.R.B. 1995. Parasites of domestic and wild animals in South Africa. XXXIV. Arthropod parasites of nyalas in north-eastern KwaZulu-Natal. Onderstepoort Journal of Veterinary Research, 62:171-179.

HORAK, I.G. \& BOOMKER, J. 1998. Parasites of domestic and wild animals in South Africa. XXXV. Ixodid ticks and bot fly larvae in the Bontebok National Park. Onderstepoort Journal of Veterinary Research, 65:205-211.

HORAK, I.G. 1999. Parasites of domestic and wild animals in South Africa. XXXVII. Ixodid ticks on cattle on Kikuyu grass pastures and in Valley Bushveld in the Eastern Cape Province. Onderstepoort Journal of Veterinary Research, 66:175184.

LAWRENCE, J.A., PERRY, B.D. \& WILLIAMSON, S.M. 2004a. East Coast fever, in Infectious diseases of livestock, $2^{\text {nd }}$ ed., edited by J.A.W. Coetzer \& R.C. Tustin. Cape Town: Oxford University Press Southern Africa.

LAWRENCE, J.A., PERRY, B.D. \& WILLIAMSON, S.M. 2004b. Corridor disease, in Infectious diseases of livestock, $2^{\text {nd }}$ ed., edited by J.A.W. Coetzer \& R.C. Tustin. Cape Town: Oxford University Press Southern Africa.

LONDT, J.G.H., HORAK, I.G. \& DE VILLIERS, I.L. 1979. Parasites of domestic and wild animals in South Africa. XIII. The seasonal incidence of adult ticks (Acarina: Ixodidae) on cat- tle in the northern Transvaal. Onderstepoort Journal of Veterinary Research, 46:31-39.

MACIVOR, K.M. DE F. \& HORAK, I.G. 2003. Ixodid ticks of Angora and Boer goats, grysbok, common duikers, kudus and scrub hares in Valley Bushveld in the Eastern Cape Province. Onderstepoort Journal of Veterinary Research, 70:113120.

MASON, C.A. \& NORVAL, R.A.I. 1980. The ticks of Zimbabwe. I. The genus Boophilus. Zimbabwe Veterinary Journal, 11:3643.

MURRELL, A.N., CAMPBELL, J.H. \& BARKER, S.C. 2000. Phylogenetic analysis of the rhipicephaline ticks indicates that the genus Rhipicephalus is paraphyletic. Molecular Phylogenetics and Evolution, 16:1-7.

MURRELL, A. \& BARKER, S.C. 2003. Synonomy of Boophilus Curtice, 1981 with Rhipicephalus Koch, 1844 (Acari: Ixodidae). Systematic Parasitology, 56: 169-172.

NORVAL, R.A.I. 1981. The ticks of Zimbabwe. III. Rhipicephalus evertsi evertsi. Zimbabwe Veterinary Journal, 12:31-35.

RECHAV, Y. 1982. Dynamics of tick populations (Acari: Ixodidae) in the eastern Cape Province of South Africa. Journal of Medical Entomology, 19:679-700.

RECHAV, Y. \& DE JAGER, C. 1991. Seasonal abundance of ticks associated with indigenous goats on a Northern Transvaal farm. Journal of the South African Veterinary Association, 62:10-11.

SCHRÖDER, J. 1980. Cattle ticks from the Waterberg district of the Transvaal. Journal of the South African Veterinary Association, 51:27-30.

SPICKETT, A.M. \& MALAN, J.R. 1978. Genetic incompatability between Boophilus decoloratus (Koch, 1844) and Boophilus microplus (Canestrini, 1888) and hybrid sterility of Australian and South African Boophilus microplus (Acarina: Ixodidae). Onderstepoort Journal of Veterinary Research, 45:149-153.

WALKER, JANE B., KEIRANS, J.E. \& HORAK, I.G. 2000. The genus Rhipicephalus (Acari, Ixodidae): a guide to the brown ticks of the world. Cambridge: Academic Press.

WHARTON, R.H. \& UTECH, K.B.W. 1970. The relation between engorgement and dropping of Boophilus microplus (Canestrini) (Ixodidae) to the assessment of tick numbers on cattle. Journal of the Australian Entomological Society, 9:171-182. 